\title{
The Cognemes of the Spanish Language: Towards a Cognitive Modelization of the Submorphemic Units in the Grammatical Words of the Spanish Language
}

\author{
Didier Bottineau \\ CNRS, UMR $7114 \mathrm{MoDyCo}$ \\ Université Paris 10 (Nanterre) \\ didier.bottineau@free.fr
}

\begin{abstract}
This study will apply to the description of Castilian Spanish grammatical words and morphemes a paradigm of principles which were originally elaborated in morphological analyses of English morphemes (Bottineau 2002, 2003a, 2004, 2006) and then evolved into typological instruments for general morphology. Before starting out on the language it is therefore necessary to summarize the way in which they apply to English. This will be done firstly for lexical units and secondly for grammatical ones. For each, the Spanish data will be set against the English ones.
\end{abstract}

\section{The submorphology of lexical units}

The Saussurean theory of the linguistic sign postulates that the link between meaning and form is essentially arbitrary and conventional in underived lexical units such as gato, cat, perro, dog: the word taken as a whole is said to refer to a unified concept and it is not possible to dissect the word into submorphemic units as one might try to dissect the corresponding concept into a series of semantic subcomponents or features. There is supposed to be no phonosymbolic iconicity in word structure at the level of the root if one leaves aside the notorious exception of the onomotopeaia. However I have suggested in various studies that the problematic is in fact much more complex than this commonplace formulation.

If one is to cling to the traditional terms of signifier for the form of a word and signified for its meaning, in written languages there are not one but two signifiers, the acoustic one and the luminous or photic one, and clearly if the meaning that one constructs on hearing he word perro is the concept of dog with a relatively consensual set of properties and pragmatic values, the immediate meaning that one constructs on reading the same written word is an acoustic score, una partitura, that is to say the sequence of syllables and phonemes by which the reader would utter the corresponding acoustic realization of the word if he or she were to turn into a speaker. The meaning of <perro> is primarily /perro/ and secondarily the canine notion. In this respect, the spelling of the written word cannot be said to be arbitrary, since its profile is aimed at prompting the reading of the word (just as the text of a play prompts the acting). The implication of this trivial statement is that phonetics can be viewed as an integral part of the semantics of written signifiers, at least in languages whose spelling relies on letters and syllabic units, as opposed to ideogrammatic writings like that of Chinese. Furthermore, the asymmetries of the two morphologies are not parallel: the acoustic sign, voiced by the emitter and heard by both receivers, only exists physically during the actual voicing and hearing because the acoustic waves are emitted by the living being endorsing the role of the speaker. Trivial as this may sound, the photic signifier is the absorbtion of natural or artificial light by the ink contrasting with the light reflected by the sheet 
of paper that bears the ink (or the other way round), so that the photic signal is not immediately emitted by the writer; it keeps being reflected as long as the paper, the ink and the light continue interacting: the lifetime of the signal and of its visual perception (which is a tiny part of it) do not coincide with that of its actual production by handwriting. The output of a speaker's phoning is direct acoustic input into both hearers' brains, whereas the output of a writer's somatic handwriting is a permanent photic signal reflected by a trace left on a surface with no direct photic input into anybody else's cognitive system but the writer himself, who also happens to be his own very first reader. A speaker directly interacts with the hearer's cognitive system and, on hearing his own acoustic output, the speaker theoretically undergoes the same stimuli as the addressee, without even realizing it, carries out the same interpretive process and double-checks the accuracy of the the uttering 1) by (re)interpreting it and 2) by visually detecting the addressee's reactions and anticipating further needs, mismatches, etc. A writer has to make do with the simplecheck of the reading. Conversely, the hearer's physical reactions (looks, mimicks, kinetics, proxemics) keep influencing the speaker's uttering, unlike the reader's. The acoustic signal is constantly being remoulded by immediate interference on both sides, unlike the photic signal, which is permanently shaped by provisional interference as anticipated by the writer. The linguistic vocal process of sentencing or enunciation is thus redefined as an orienting process (in Maturana's sense) in which either or both interpreting consciences are made to experience inunciation, the mustering of recorded heterogenous semantic prototypes (labelled by lexical units) which are to be assembled into a coherent and dynamic mental piece of experience following a procedure formatted by the language's syntactic patterns and involving a vast but limited gamut of combining processes labelled by grammatical morphemes (articles, auxiliaries, inflections, particles, free and bound morphemes of all kinds in linguistic typology).

The resulting meanings (distributed over all oriented consciences involved, speaker's included, and varying accordingly with personal, psychological contexts, and to be concerted and realigned through negotiation) may or may not match the perceived "external reality", but they will never coincide with it as by definition linguistic meaning stems from a combination of "vocal proustian madeleines" to be set against the immediate data of empirical experience acquired through sensations: human consciousness is borne out of this constant dialogue between perception and, literally, evocation. Intelligence, literally (inter-ligere), features the amplifying effect of vocal words connecting singular experience with recorded and evolving types acquired through multiple experience. Speaking is thus understood as an ideating or idea-forming procedure (Bottineau 2007) in which meaning is the final output rather than the initial item to be symbolically transcoded from a putative cognitive mindscape into a somatic, behavioral, sensori-motor one: to speak is to make one(self) form an idea to be set against the "situation" (both material and psychological) in which the act of speech occurs so as to achieve concerted thinking in which the idea opposes rather than reflects the sensation.

Ordinary communication, understood as the somatic transmission to the hearer of the speaker's intended meaning by motor action upon the perceivable environment, is only a particular case in which meaning was actually planned in the first

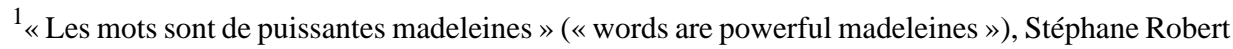
(conversation).
} 
place. Not only can one doubt that this is ever the case, but it falls short from explaining why language is also used as an intimate idea-forming process for oneself in the case of silent thinking - a situation in which the idea that sentences express ideas must be rejected: actually they impress them in a "thoughting" process. To think is to mentally anticipate what the auditory proprioception of the corresponding vocal sentence would be if it were actually voiced rather than inhibited (as is daily experienced by any person on his or her own who will tend to mutter rather than silently think), neural speech having the prosodic features of vocal speech (tone units and profiles, variations in rhythm and intensity, and so on): to think is to cause oneself to form ideas through the "virtual experience" of inunciation of nonvocalized sentences. This results in suggesting that whether meaning is planned or not (communication vs thinking) the linguistic procedure as a motor-sensory-cognitive function of distributed co-ideation involving brains, bodies and the medium is shaped to operate as an idea-forming "vocal tango" that does not rely on any other intended meaning than the very need to form an idea that will be matched against the currently experienced situation, and this procedure is shared by both thinking and telling: ideation is conveyed by an orienting procedure whose effect is both transitive and reflexive, that is, distributed, negotiated and concerted between all the linguistic participants in the dialogue (the interlocutors), in the environment (the atmospheric acoustic waves and the human beings) and the internal dialogical relations between neural, nervous and muscular sensori-motor dynamics for each individual living being. In this perspective, the linguist's task is first and foremost to plot the vocal scenario of the ideating procedure such as it is evidenced in the various languages: syntactic patterns itemize the various steps of the "assembly line" in fixed or varying orders; the lexicon provides the "madeleines" required for retrieving the notions synthetizing the empirical knowledge aggregated through random individual and social experience of the environment; and grammatical morphology (if any) provides the key to re-activating the combinatory processes required to connect the lexical items into a network involving direct semantic relations between lexical types (notion and quality: white dog) and between those types and the dialogical situation under current scrutiny (determiner and noun: $a$ dog - a type for which no current occurrence can be retrieved from the acquired experience of the situation and conversation, whether the orientee be the hearer or the thinker). So the question raised in this study about Spanish is whether any relevant data for modelling the ideating process can be found in the very phonological structure of grammatical morphology.

It follows that, blunt as this may seem, the signifier as Saussure describes it is a mere fiction which only exists in the linguist's mind. What does exist in the physical world is the signifier as it is emitted by the one speaker and the signifier as it is captured by the two receivers of the acoustic sequence, if we content with focussing on the acoustic sign. In the first case, the sign is a neuro-motor program lauched by an intention to trigger off the emergence or instantaneous selection of a certain type of representation in the targeted receiver's mind; a program which translates into a set of behavioral patterns that are basically concerned with the modulation of the outgoing air flow in order to generate articulated acoustic waves. For the speaker or writer, the sign is therefore the ritual execution of a physical procedure driven by mental purposes. In the second case, for the hearer or reader, the sign is a recognizable perceptual pattern connected with a semantic representation (whatever this may be), a sensitive sequence that translates into a semantic one once a 
critical threshold of recognition has been trespassed, making it possible to make the decision to select the relevant notion. Obviously the way in which the signifying procedure is perceived also varies greatly depending on whether one focusses on the emitter's or receiver's part and the whole question of iconicity is to be reconsidered by taking into account the differenciated paradigms of senses implied in each and the nature of the iconicity under scrutiny.

The English lexicon provides a rich example of this difficulty, which is marginally evidenced in Romance languages. The so-called nordic monosyllabic stems usually comprise one or several consonant clusters in initial or final position known as ideophones or phonaesthemes (Firth 1930; Philps 1997, 2003) (capital letters are used when both the photic and acoustic signs are considered). ST refers to the notion of fixity o stability as in stay, rest, stand, still; SP to that of rapid rotation and ejection by centrifugal force as in spear, spin, spend, spill, spread; WR to the notion of constrained rotation as in wrist, wriggle, wry, wreck. I have shown that if the ideophone is located in the onset of the syllable, it will provide a semantic classifier expressing a property that encompasses the whole notion, wheras if it is sited in the coda it will express a salient property that may not be sufficiently prominent to serve as an overall prevailing classifier. Moreover, the meaning of ideophones is not so much concerned with the physical properties of objects as they are perceived visually as with the prediction of the type of behaviour the object is apt to have in common experience (the stump is the part of the object that will stay when the rest is removed) or of the type of behaviour which a human agent may embark on when confronted with the object. If the viewer contents with visualizing an anticipated behaviour, the interaction is absolutive (a spear does not spin, but is cast by means of a spinning movement of the user's arm); if the viewer suggests a potential interaction with an agent, the interaction is ergative (characteristically, a sponge can be caused to spill, spray or sprinkle water if constrained by a spinning movement of the user's hands: sp- points to neither the shape of the thing, nor a potential behaviour, but a potential agent, an expected typical spinner as it were). This amounts to engraving in a notion a submorpheme bearing the relational potentiality extrapolated from the experience and memory of previous encounters with its referent. A Basque example is eguzki "sun" with gu ("light") and $k i$ (an infix which ordinarily introduces a pronoun understood to be in the dative in verb morphology), the whole meaning "the light given to (anybody)", the light permanently befalling any implicit receiver. In stump and sponge, the absolutive or ergative targeting of the interaction ST and SP remain unmentioned; in Basque; the dative targeting of $g u$ is displayed by $k i$.

This approach to morphology should not be hastily dubbed as cratylian or phonosymbolical : so long as one does not contend that the semantic value of the cluster is iconically motivated by the physical properties of the sounds they are made up with and such as they are perceived by the emitter, the receiver or both, there is no phonosymbolism, but only a recession of the frontier of morphology, since the ideophone SP may be just as arbitrary and lacking in motivation for referring to centrifugality as gato is devoid of phonosymbolicity for pointing to the miaowing mammal.

Whether the Spanish language displays the same type of submorphological consistency is far from evident. Some of the consonant matrices corresponding to the clusters of English do indeed exist: 
$\mathbf{S}+\mathbf{P}$ : esperar "to wait for, to hope" (projection), espejo "mirror", especulación, especie, espacio, despojar "to spoil", despensa, despreciar "to despise", litterally "to *disprize", despegar "to take off".

S+T : sitio "place", "site", situar, bastar "to suffice", justo, estar circumstancial "be"from latin stare, "stand" (and all its derived forms), desde "since", hasta "till", "until", satis(facer) "satis(fy)".

However the number of exceptions seems to be far greater than in English, and the very hypothesis that those consonantal combinations might belong to semantically relevant matrices is indeed a risky one since they appear in reduced numbers and in locations that do not clearly correspond with ordinary morpheme boundaries. As in English the combination of $\mathrm{S}$ and $\mathrm{P}$ results from various diachronic origins (des- or $e x$ - + root starting with $p$ ) but unlike in English these concurring etymologies are not made to coincide in one single morpheme which is clearly used as a unifying classifier $s p$-. English young children are sometimes told that $d o g s$ dig with a shared ideophone which is not connected with auditory perception and is not onomatopeic, while Spanish ones are told that el perro gruña "the dog is snarling": onomatopeic echoing $r$ s in Spanish do not make up ideophones. Whether the Spanish lexicon displays a relevant submorphology remains unsure (other than occasional onomatopeiae), much more so than in English. Be that as it may, lexical submorphology deals with programming behavioral predictions attached to the object or to a potential animate agent that might interfere by using or facing it rather than to the visual and descriptive properties of the referent. We shall now turn to the semantics of submorphology in grammatical morphemes, which is based on a set of essentially distinct principles which do not serve the same type of semantics.

\section{The submorphology of grammatical words}

As is well known (Danon-Boileau 1983, Lapaire \& Rotgé 1993, Viel 1993) some English grammatical morphemes display some degree of morphological consistency. Two cases in point are the alternations of two vowels, I and A, and of two consonants, WH- and TH-. The operators marked in capital letters refer to the semantic core values associated with the corresponding phonemic and graphemic realization, considering that the acoustic vowel varies according to stress and syllable structure (cf. $a$, that, what, all) and was made to change positions during the Great Vowel Shift ; and the photic one usually comes out as $\langle\mathrm{i}\rangle$ but also as $\langle\mathrm{e}\rangle$ as in be, etc.

I allegedly deals with the notion of proximity, as opposed to A, which conveys that of distance or distanciation. This is to be found in demonstratives this and that and in interrogatives which and what, with which selecting a relevant referent among a group of several in praesentia, and what implying the research of a referent in absentia.

TH is a marker of anaphora as opposed to WH or cataphora (Adamczewski \& Delmas 1982, Delmas 1987): when designates a moment in time whose referent remains to be pinpointed, as opposed to then, which anaphorically refers to an already known space in time. The same analysis is valid for where and there, which and this (which calls for the selection of a referent in praesentia and this anaphorizes it), what and that.

The theory of cognemes proposes a generalized recognition of submorphemic indicators wherever they are to be found in grammatical morphology. The word cogneme designates a semantic process that the speaker invites the hearer to implement in order to establish a relation between two preexisting semantic entities, 
a cognitive hinge available in the linguistic system shared by the addresser and the addressee that the former can activate in the latter's mind by sending the relevant acoustic trigger sound in the appropriate syntactic environment. In the case of I, the instruction consists in joining or even merging two previously seperate entities. The nature of the semantic entities involved depends on the format of the syntactic units between which the cognemic submarker is operating. It may be two lexical notions:

Adjectival suffix $\mathbf{- y}$ : creation of single notion obtained by combining without any restriction the previously separate notions corresponding with underlying substantives. An icy moon is a moon whose visual perception is best summarized in one single noun, namely ice. A dusty cloud is a cloud whose first perception is best or primarily rendered by the word $d u s t$; this also applies to more abstract combination like a testy letter, a thundery voice.

Be: I may intervene between two phrases, the subject and the predicate, in which case it commands the combining not of the prototypical notions, but of their referencial referents after they have been processed by nominal determiners: A camel is a mammal. This sentence is cognitively relevant if and only if the speaker considers that the connection between camel and mammal does not preexist in the hearer's system of organization of semantic representation of the universe. In using this submorphemic marker of unrestricted assimilation, the speaker aims at inviting the hearer to create the hyperonymic relation which is taken for granted by logical analysis, which does not take into account the makeup of its own patterns in individual cognitive systems.

Demonstrative this: Finally I may intervene between a couple of other submarkers, such as in $\mathrm{TH}$ and $\mathrm{S}$ in this:

(1) In some scientists' minds, the small, round structures featured in this microscopic sample of Martian clay may be fossilized microbes. (Sky and Telescope, June 1999, How far the stars?, p.24)

In demonstrative this, three submarkers are present: $\mathrm{TH}$ for anaphora - the speaker invites the hearer to locate in the physical world the object he or she is talking about and which is supposed to have already been detected or mentioned; $S$ for present definition: $\mathrm{S}$ indicates that the nomination that followed is a novel one in the context, in this example the reader was not supposed to have identified the content of the photograph described as being a "sample of martian clay"; and finally I in between to provoke the assimilation of the semantic entity captured by $\mathrm{TH}$ through the anaphora and the one captured at the same moment by $\mathrm{S}$ introducing an operation of present naming ("nouning" would be more accurate). In terms of neural networks, this implies that anaphora and nomination are computed separately before stringing together their results as commanded by submarker of assimilation I. The overall core value of this may be summarized by a set of instructions corresponding with the individual submarkers. What you now remember $(\mathrm{TH})$ is made to coincide (I) with what you now discover (S):

THIS

[ASSIMILATE] (I)

$\{\mathrm{TH}=$ what you now remember $\}----------\{\mathrm{S}+$ NOUN $=$ what you now discover $\}$

When "what you remember" fully coincides with the preceding phrase, the anaphora goes without marking: this minus TH is is, in instructional terms [ASSIMILATE] (I) $\{$ what precedes $\}$ (zero) and $\{$ the following concept $\}$ (S). At this 
stage, it should be clear that this cognitive semantics has nothing to do with any kind of cratylian symbolistic motivation whatsoever. One does not say Take this chair, I'll take that one just because the first one is the nearer and the second one the more distant of the two, but because the thing is pinpointed by a movement of the hand that makes it anaphorizable at a time when the corresponding class remains to be named, this chair, whereas in the second occurrence the class has already been selected, which is indicated by T, contrary to the real chair, which is distinct from the first one and remains to be anaphorized separately. In the case of this, anaphora and nomination coincide in cognitive sequence, so that they are assimilated by I. In that of that, the TH anaphora, which is carried out at the very moment of utterance, is to be dissimilated by A from the naming process, which is relegated to the cognitive past of preconstructs by the $\mathrm{T}$ marker.

THAT

[DISSIMILATE] (A)

$\{\mathrm{TH}=$ what you now remember $\}-----\&-----\{\mathrm{T}+$ NOUN $=$ what you then discovered $\}$

This paves the way for an implicit reassessment of the properties of the referent at the time of utterance, and the choice of that often has semantic implications which are to be interpreted in the context: This is Richard, and this is Kathy introduces both characters; This is Richard, and that is Kathy may be ironic: Kathy may have an appearance or attitude which in itself is already an indicator of her characteristics so that in using that the speaker is pointing to symptoms that call for a predetermined diagnosis.

The English language displays a whole range of such markers. Before itemizing them and turning to Spanish it must be made clear that a sound does not intrinsically refer to a cognitive procedural instruction. One phoneme will activate its twin cogneme only if some requirements are satisfied: the submarker has to be made detectable and validated as such by belonging to a network of alternations marking contrasts. WH will be identified as a submarker because its alternation with $\mathrm{TH}$ is regular (when / then) and marginal operators like who or why may be included despite their lacking a counterpart beginning with TH because they belong to the same functional paradigm. This excludes lexical units like whale, whim, whistle, thistle, thorn, thumb in which $\mathrm{WH}$ and $\mathrm{TH}$ do not relate to cataphora and anaphora because they do not oppose one another, nor do they belong to any word class which does so. I and A oppose processes of assimilation and dissimilation in this I that, which / what, the / an, is / as, is / was, swim / swam because their belonging to a common network is underlined by common denominators that may be semantic and functional (be and have), sometimes also morphological (swim and swam, with the ideophonic element SW as in sweep, sweat, swear, swoon, all of which share the notion of oscillation, pendular motion). Conversely, in the pair pin / pan, the I/A alternation is just as irrelevant as $\mathrm{P} \_\mathrm{N}$ as an ideophonic marker: sounds will not be made to mean a cognitive process so long as their belonging to a systemic network is not obvious. It is now possible to give a brief sketch of the English cognitive morphological system in grammatical morphemes: 


\begin{tabular}{ccc}
\hline U & I & A \\
[TARGET] & [ASSIMILATE] & [DISSIMILATE] \\
\hline do & be & have \\
look & see & watch \\
to & in & at \\
do & did & as \\
foot & feet & was \\
& is & \\
the & is & an
\end{tabular}

\section{R/S/T: [INCHOATE] / [CONTINUE] / [DISCONTINUE]}

high > higher, highest (high: average; higher: beyond high applied to an entity of the same kind; highest: exhausiton of higher)

is (assimilation at the moment of utterance) / it (assimilation to some pre-identified notion that need not be made explicit because no further calculation is implied, cf. that)

yes / yet (present and past approval: concession)

no / not (negation and its anaphorization)

plays / played (validation / rejection)

\section{WH / TH: [POST] (cataphora) / [ANTE] (anaphora)}

which / this, what / that, where / there, when / then

\section{N: [REJECT] (negation)}

In initial position:

no, not, nor, none, naught, now (vs yet), nil, null, new

In final position:

in $=$ restricted assimilation : integration

$A n=$ restricted dissimilation $=$ extraction with no qualitative distinction

-en $($ driven $)=$ the one that does not drive, shaven $=$ the one that no longer shaves (that is marked by the result, not the operation)

\section{L: [PROJECT] (future)}

will, shall, still, till

Each gramatical operator thus appears as one global semantic procedure endowed with a complex core value engineered by a set of elemental cognitive instructions marked by individual components, hence some remarkable systems like to / till, yes / yet, no / not etc. An operator like still combines ST for stability, permanence (itself a combination of $\mathrm{S}$ for continuity and $\mathrm{T}$ for interruption) and $\mathrm{L}$ for futurity, which accounts for both the spatial and temporal meanings of this highly polyfunctional word (still water, still better, still at work, and still...).

\section{Submarkers in the Spanish language}

The Spanish language does not use submorphemic markers of cognitive processes with such a high degree of consistency as English does but there do appear to be remarkable regularities. It is not possible for the Spanish language to argue that the engineering of grammatical relations sytematically revolves around the marking of basic cognitive patterns as it is the case in English and the phenomenon, to be accurately described, must be granted its due importance, no more, no less. This exploratory section aims at introducing representative systems involving such dynamics but will not pretend that the organization of morphemes is to be reduced to 
this principle. The question why it operates as a trend that imposes itself unequally in one language as welle as among languages is to be broached after some preliminary investigation.

\section{I/A: aquí / acá, allí / allá}

Aquí merely presents an introductory specification about the here the speaker wants to pinpoint: the location in space is selected as opposed to the rest of the paradigm of all the other potentially relevant places the term might cover. As clearly appears in the following example, aquí aims at providing a heuristic approach of spatial location: the informational import does not go beyond what the word aqui means literally, the place where the speaker happens to be at the moment of utterance, which the hearer is to construe either implicitly, on the basis of direct perception of previosly known information, or by direct explicitation as in the following example:

(2) Aquí, en las antípodas, hemos ganado la libertad quitándonos la ropa.

(2') Here, in the antipodes, we have gained our liberty ridding / stripping ourselves of our clothes.

Acá implies additional secondary values: the here is defined in relation to the hearer and suggests some pragmatic implications. The speaker does not only aim at defining his own location but at recalling it (los de acá: the people who live here with their specificities). In most cases, the use of acá implies that the speaker considers that the hearer is already fully aware of the aqui he or she is referring to so that the mere replacement of I by A implies anaphorization and distanciation, clearly suggesting that the pragmatic value of the utterance is not informative, but interpersonal, an injunction in many cases; or that the informational value does not coincide with what the word literally suggests and calls further pondering. The choice of the modalization supported by the A anaphora is usually conveyed by prosodic indicators: ¡Ven acá en seguida! "Come here at once!” The same holds true for allí and allá :

(3) Normalmente, en la época de los descubridores, cuando se llegaba a un sitio nuevo, se encontraban tribus indígenas que se habían instalado allí desde mucho tiempo atrás, decenas o incluso cientos de miles de años.

(3') As a rule, in the days of the explorers, in every new place there were indigenous tribes which had settled there scores before, tens or even hundreds of thousands of years before.

The site is new for the pioneers, but also for the reader, as is indicated by the indefinite article un sitio nuеvo.

(4) Es un lugar muy frío y seco. No me gustaría vivir allá. (conversation)

(4') It's a very cold and dry place. I wouldn't like to live there.

Alli would simply mean in the place I have mentioned (with a heuristic, open value) whereas allá also includes the qualification of it and saturates the interpretation (anaphora bearing a hermeneutic value). In the same way, más allá (de) "beyond" presupposes that some place other than alli is predefined, which can no longer take the heuristic form, hence * más allí, which is, from a cognitive point of view, contradictory in terms. This use of the I/A contrast is not an isolated case. It is to be observed in very similar conditions in Italian with the homologous deictics qui / qua, lì / là (sono qui "I'm here", vieni qua "Come here!"). The French language, which does not have a pair of operators matching aquí and acá, goes so far as us- 
ing là for $i c i$ whenever the speaker considers that the place is situationally predefined and loaded with pragmatic implication: Viens ici! "Come here." The speaker shows the place in question but gives no indication about what is to happen to the hearer once he or she gets there, unless some specific intonation, rhythm and stress sugest a strict order). Viens là! "Come here!" The speaker indicates that the hearer is supposed to be aware of the event which is to befall him or her in the location in question; the implication might be, if I am to comb your hair, you must sit on this chair instead of fooling around. Because the interpretation is saturated ${ }^{2}$, the hermeutic form explicitly places the speaker in a dominant position with a notable lack of consideration for the addressee which contrasts sharply with the heuristic form even if the prosody bears a strong injunctive intention ${ }^{3}$.

In wolof, an African language of the Atlantic group mostly used in Senegal, a substantive is ordinarily followed by a consonant indicating the class to which it belongs ( 8 for the singular and 2 for the plural), and then a vowel for spatial location: I in the case of proximity or heuristic localization (xale bi "this child"), A in the case of distanciation or hermeneutic location with interpretive or pragmatic implications (xale ba "that child"), $\mathrm{U}$ in the case of spatial indetermination, or, to be more accurate, in the case in which spatial localization has not been carried out yet and remains to be accomplished by some additional semantic specification as in xale bu jygéén (child-who-girl = "the little girl"; the child you may identify by spotting the one bearing the female trait, which by-passes spatial localization).

The striking fact is that the same value is attached to homologous sounds in natural languages which are not supposed to be connected by some common mother tongue, and even if this were the case, there would still have to be some other principle to account for the persistence of the link between form and meaning. In the case of I and A it is of course tempting to consider the properties of the sounds and assume that I was been selected for expressing junction because to utter an /i/ is to enact a contact between the tongue and the velum and to hear an /i/ is to detect the higher of the two formants, which is apt to mimick proximity on account of the

\footnotetext{
${ }^{2}$ Douay 2000 proposes a theory of interlocutive relations according to which morphemic alternations stage the possibility to choose between various dialogic configurations in the semantic domain discussed by the marker (be it a determiner, a deictic, an auxiliary etc.) in terms of contrasted vs concerted commitments. As it happens, cognemic analyses often happen to arrive at analogous results: in romance languages the $i / a$ contrast in spatial deictics is regularly underlaid by a spatial analysis of the dialogical assignment of grammatical values to each of the interlocutors.

${ }^{3}$ In Douay \& Roulland's theory of interlocutive relations (Douay 2000) grammatical alternations are envisaged not so much as speaker-based markers of location in space, time, modality etc. as as markers of prototypical attitudes to be adopted by the hearer or receiver of the utterance in the process of interpreting the message. A threefold schema is postulated: (i) Configuration 0 , in which immediate dialogical agreement between the interlocutors over the semantic issue discussed by the grammatical system of operators can be obtained directly in the context of the dialogical interplay; by contrast, Configurations 1 and 2 stage two profiles of the potential mismatch that may oppose the interlocutors' viewpoints and require further metalinguistic discussion. (ii) Configuration 1 stages the potential dialogic contrast: the speaker endorses the validation of the semantic choice albeit the hearer's position is regarded as potentially different: potential dissent is emphasized. (iii) Configuration 2 stages the case when the agreement between the interlocutor's stances is taken for granted, leaving no possibility for the receiver to assume his own difference: potential dissent is neutralized. This cognitive apparatus shaping interlocutive profiles is diversely instantiated by grammatical systems in their own semantic field: determiners $(\emptyset$ : $\mathrm{C} 0 ; a$ : $\mathrm{C} 1$; the: $\mathrm{C} 2)$, deictics (this: $\mathrm{C} 1$, that: $\mathrm{C} 2)$, modals (can: $\mathrm{C} 1$, may: $\mathrm{C} 2$ ), etc. As it happens, cognemic analyses often happen to produce analogous results: in romance languages the $i / a$ contrast in spatial deictics is regularly underlaid by the spatial positioning of the dialogical source(s) that the speaker regards as responsible for the paradigmatic selection. In the dialects of Spanish and Italian that do not neutralize the $i / a$ contrast in spatial deictics, the same analysis may be applied. In short, cognemes may be used as the markers of how intersubjective distribution is concentrated at the level of the semantic issue discussed by the grammatical microsystem.
} 
Doppler effect, according to which any incoming sonorous object will be perceived as emitting a sound whose pitch is actually higher than the frequency at which it was originally emitted; and, conversely, A could be alleged to mimick distanciation because of both the manner of articulation and the perceivable formant at conscious level (Arapu 1988). Yet this kind of analogy seems improbable, difficult to demonstrate, and will not apply to all sounds since only the most extreme sounds like I and A display such an obvious connection between the features of the sounds and those of the semantic processes that may be derived from them.

The latter wording may be the key to understanding the true nature of the process: it is not the sound that is selected on account of its capacity to mimick a cognitive process, but, on the contrary, the cogneme itself whose very pattern is derived from that of the production of the sound. If I rests on a neural program consisting in performing a connection between two articulators, the cogneme that may be derived from it is a semantic procedure consisting in generating the same type of conjunction between two semantic entities which have replaced the articulators. My current interpretation of the phenomenon is therefore that cognemes are a kind of semantic software derived from a phonological one, at least when they originally came into existence. Once the semantic programs stabilize, their attachment to the sounds which generated them becomes unnecessary. Some languages opt to maintain some degree of cohesion between the sound and the structuring of sense but it is theoretically possible that this relation becomes entirely bleached. Spanish seems to have retained residual traces of the phenomenon in linguistic functions of exceptional relevance an sensitiveness for that matter, like the expression of spatial location, which happens to be based on computing relations of assimilation and dissimilation. An intermediate situation is to be found in English, in which major phonological changes such as the Great Vowel Shift have widened and diversified the gap between the properties of current sounds and those of the cognemes which were derived from their original counterparts in more primitive versions of the phonological system. That is the reason why a cogneme like I for junction may be displayed by a whole range of phonemes determined by syllable structure and stress patterns: I, this, be all bear the same cogneme under various semiological manifestation. The derivation of the cogneme from the sound is an historical phenomenon which occurred at a given moment of the history of human cognition, which may then be followed by an alteration of the link between sound and sense which does not affect the semantic side of the stabilized cogneme.

Concerning I and A, these vowels are known to be the extremities of the vocalic triangle which encompasses all phonological systems in the languages of the world and therefore constitutes a universal, even if there exists an infinite variety in the ways in which Is and As may adjust to the rest of one phonological system as it grows ever more complex. This universal trait need not imply that all languages descend from just one mother tongue as Ruhlen would have it: if the vocalic triangle is motivated by biological constraints, so are the cognemes that may be derived from its poles, so the same semantic procedures may have evolved in different places at different times just because this natural cognitive phenomenon remains universally available for further development and renewal. Thus the theory of cognemes does not confirm Ruhlen's hypothesis even if it is not incompatible with it: the derivation of semantic patterns from sound production is compatible with a polygenetic view of the origins of language. If we are to disentangle the 
question of the origins of cognemes, the first thing to do is to dissociate it from that of the origins of language itself.

The theoretical interest of this model is that it dramatically reduces the cost of cognematics and predicts the kind of situation which is actually observed in the languages of the world: as I and A are available starting blocks for deriving cognemes, the latter may emerge sporadically at any time and in any place in human language, but need not do so or may become historically concealed as capricious phonological systems drift away from them, so that the phenomenon is both sporadic and universal: relatively exceptional in its most spectacular occurrences, but remarkably and abnormally consistent if one is to invoke fortuitous coincidence. Let us now turn to other similar cognemes in the Spanish language.

\section{2. $R, S$ and $T$}

In the case of English the $\mathrm{S} / \mathrm{T}$ alternation in grammatical morphemes is rooted in the present / past dichotomy. If formulated in these terms, this system is not to be found in Spanish in the conjugation of the imperfecto (imperfect) and of the pretérito definido (simple past). However $\mathrm{T}$ is to be found in the voiced form $/ \mathrm{d} /$ in the past participle which is derived from the latin form: -atus $>-$ ado, cantado and in other operators dealing with other forms of completion like todo (total inclusion) and nada (total exclusion). S and $\mathrm{T}$ share the same place of articulation and are differenciated by their modes of articulation, with /s/ bearing the trait of continuity and / $t$ / that of plosivity, which is to say, discontinuity. In cognemic terms, the procedural instructions derived from them are respectively [CONTINUE] and [DISCONTINUE] the process to which $\mathrm{S}$ and/or T are applied.

The case of $\mathrm{R}$ is trickier as this graphemic consonant coincides with an extremely versatile bunch of consonants in the various phonological systems, but there is some reason to assume that primitive $\mathrm{R}$ is systematically apical as in Spanish and English (albeit in very different ways), which places it in the same position as $\mathrm{S}$ and $\mathrm{T}$. In this system, R, S and T correspond to three different ways of treating the air flow in the same position. In substance, $\mathrm{R}$ consists in posing an obstacle on the direct path of the air flow, so that the latter has to be forced out by raising the air pressure and a lateral deviation. The interaction can be made sonorous by a movement of the tongue (Spanish erre) or by the use of the mouth as a resonating cavity (American dark $r$ ) but the physiological undertaking is the same: one way or another the speaker makes it heard that an effort is required to propel the air out of the oral tract, with the tongue interposing itself as an obstacle. The resulting cognitive reinvestment of this physiological procedure encodes an instruction of launching or initiating a process, of making an effort to trigger an event, in one word an impulsion. The system is thus complete, with R encoding [IMPULSE], $\mathrm{S}$ for [CONTINUE] and T for [INTERRUPT].

For this reason occurrences of grammaticalized R in Spanish (and in Romance languages in general) are commonly associated with the notion of potential agentivity. This concerns the infinitive in the first place: the infinitive verb phrase cerrar la puerta invites the hearer to construct a representation of an event, (to) close the door, in which the specification of a specific agent is missing. Hypothesizing a core value for infinitival $-r$ is all the more legimate if one relates this with other studies which have consistently insisted on the relevance of vowel alternations in the infinitive of romance verbs such as -ar, -er and -ir in Spanish (Tobin 1993): a variable marked by a vowel is set against a constant marked by a consonant. In 
cerraR la puerta, $\mathrm{R}$ stands for the virtual agent which is substituted for the actual one which could have been instanciated by a specific subject: Juan cierra la puerta "Juan closes the door"; the subject Juan forefronts one unit extracted from the paradigm labelled by $R$. R of potential agentivity is not incompatible with the mark of an actual agent unless it is distanced by A, in which case it implies mere futurity: Juan cerrará la puerta. Futurity may be virtualized in its turn by retracting word stress to the previous syllable: antes de que Juan cerrara la puerta "before Juan closed the door". This form of the subjunctive is essentially a virtualized future, one that the speaker has given up looking forward to, unlike the rival se-ending form (cerrase), which expresses a hypothesis motivated by contextual determinisms and therefore deserving to be considered more seriously :

(5) Supongamos que la artesa oceánica estuviera dividida por una colina o por una cresta, de forma que determinase una cuenca polar y otra ecuatorial.

(5') Let us imagine that the ocean basin is divided in two by a range of hills or a crest which separates a polar trough from an equatorial one. (literally, "in such a way that it determines a polar trough and an equatorial other one").

(6) Es casi seguro que Venus fuese humedo durante su formación, pero su superficie esta ahora completamente seca.

(6') It is almost certain that Venus was humid at the time of its formation, but its surface is now completely dry.

The same effect is obtained when $-r a$ anaphorizes a preconstructed hypothesis out of which -se extracts a new one on which the speaker draws the hearer's or reader's attention :

(7) Suele hacerse referencia a los cometas diciendo que son bolas de nieve cósmica sucia, mitad hielo y mitad polvo. Christopher F. Chyba estima que bastaría con que el 25 por ciento de los cuerpos que chocaran con la Tierra durante ese período final de máximo bombardeo fuesen cometas para que hubiesen aportado toda el agua de los modernos océanos.

(7') Comets are usually regarded as cosmic balls of dirty snow, half ice and half dust. According to Christopher F. Chyba, it is required that only 25 per cent of the bodies which collided with the Earth during the final period of intense bombardment be comets to have imported all the water of the oceans we know.

In Romance language $\mathrm{R}$ is also commonly used in adjectival and nominal suffixes to imply potential or virtual agentivity or its weaker version, the [animate] feature. Added to a past participle, $\mathrm{R}$ refers the result of a process to a potential agent: calentador "heater", bienhechor "benefactor" (with the same construction: past participle fact- $+\mathrm{R}$ ). In the same ways, words in -ero refer to professional agents producing the object mentioned in the radical: panadero "baker", cocinero "cook". In this construction one must distinguish the mark of potential activity (R) from the gender suffix $(o / a)$ which implies a person of the masculine or feminine sex and refers an actual agent to the principle of activity fixed by $\mathrm{R}$; this double mark of person makes it possible to distinguish the actor from the function. To prove the point, if one deletes the final $o / a$ alternation to replace it by $-i a$, one obtains panadería "bakery" (when such a manipulation is relevant) which retains 
the expression of the function associated to the virtual generic agent, R, while replacing the mark of the specific actor (o/a) by another suffix referring to the site of the activity.

In nouns like calor "heat", amor "love", esplendor "splendour", -or typically involves a virtual agent as the one who perceives the property in question, whether it is to be found within a human person (amor) or outside (calor). In French a whole gamut of suffixes express different shades of meaning (chaleur, froideur ( froidure, amour): -ure merely poses the virtual agent as the subject of perception of the quality, without his or her passing any judgment or appreciation on it, so that there only remains the trait of duration (froidure); - eur adds a modal evaluation (and is thus connected with -eux/-euse, -oso/a): chaleur.

The suffix - ar involves a virtual non human agent in an adjective: la energía so$l a r=$ the energy produced by the sun; la fuerza muscular = produced by the muscle. This may explain apparent irregularities in the distribution of suffixes in one given languages and also the lack of parallelism between two correlated idioms. $\mathrm{La}$ energía solar is l'énergie solaire in French and the solar energy in English, but la energía eólica is l'énergie éolienne, "eolian / wind energy" : Spanish uses the suffix -ico which is used for marking an abstract class or category of objects, whereas French uses -ien which designates the geographic or conceptual frame of an entity (Italien: that which belongs to Italy; divin, divino, divine: that which belongs to God). Owing to cultural differences in literary traditions such as the Eolian Harp Eole has not come to be so commonly known as to allow the adjective eolian to be so popular and untechnical as éolien in French or eólico in Spanish. If no language has ever generated *eolar or *éolaire it is because the pagan god mentioned in the radical is not presented as the agent generating the entitity under scrutiny, the energy. Eolien and eolico may refer to the same semantic class, but they do so following different mental paths (framing vs classifying): in theory *eolar is not an impossibility as it would not be semantically irrelevant to view the god as blowing the wind, which is the case in pictorial representations indeed, but the rivalry between this way of depicting things and the preexisting ones is unproductive, almost unprofitable and has probably condemned *eolar to lose the competition even before attempting to take part in it. Alimentario involves potential agentivity, as opposed to alimenticio (dictionaries consider them as purely synonymous); French only has alimentaire.

$\mathrm{S}$ instructs the hearer to [CONTINUE] the process to which it is applied.

The most obvious case is the plural of nouns: perro "dog" merely evokes a prototype, perros instructs the hearer to prolong the research of the referent until all possible occurrences have been covered. Whether this may be applied to the second person singular of verbs remains unclear.

The latin paradigm (in the singular) involves a three-step movement from a starting point, amo "I love", an intermediate position, amas and a final one, amat and the S/T alternation reflects the way in which the second and third persons are derived from the first one. This leads one to see a parallel between two ternary systems, that of aspect with the infinitive, the gerund and the past participle on the one hand, that of person on the other with the first, second and third persons, the latter taking a suffix relatively analogous to that of the past participle, a dental T. Many modern romance languages have eliminated the mark of the third person singular, breaking away from this parallelism in favour of a new order. 
More marginally, $\mathrm{S}$ is used in to local subsystems: ante / antes, quizá / quizás. Ante is spatial and abstract, antes converts it into a temporal relation, in conformity with the core meaning of S. Quizá (meaning maybe or perhaps) expresses a lack of certainty affecting the validation of the predicative relation, hence the use of the subjunctive:

(8) Pero el éxito del alimento quizá provenga de otro elemento detectado en su composición : un aminoácido implicado en la creación de serotonina, neurotransmisor responsable de las sensaciones de felicidad.

(8') But perhaps the success of this food comes from another element detected in its composition: an amino-acid involved in the creation of serotonin, the neurotransmitter responsible for the sensations of happiness.

Quizás focalizes the very process corresponding to the uncertainty under scrutiny:

(9) Una idea que servirá, quizás, un día.

(9') An idea that might come in handy some day.

In both cases, $\mathrm{S}$ is used for validating at the moment of utterance the operation specified by the rest of the operator.

In Castilian $\mathrm{S}$ is frequently combined with $\mathrm{T}$ in grammatical morphemes. This cluster ST instructs the hearer to conduct a mental process (S) until its final limit (T): desde (since), hasta (till, until) and justo (just). Desde prescribes a mental path oriented toward an origin viewed as the final limit of the trajectory; hasta prescribes the same movement in the opposite direction; justo prescribes the hearer to mentally attain a threshold which is neither the beginning nor the end of a semantic domain and has to be defined in qualitative rather than topological terms.

A remarkable illustration of this alternation of $\mathrm{S}$ and $\mathrm{ST}$ in Castilian is provided by two parallel grammatical systems, that of the two verbs be on the one hand, that of the demonstratives on the other. The verb ser is used to aggregate a new property to the cluster of features which already constitute the notional prototype (or to introduce a new linguistic label for this property): La nieve es blanca, "snow is white". In referential semantics, the verb ser may seem to describe an immutable state of things, but in cognitive semantics, its real function is to enable the speaker to permanently modify the system of representation of the hearer around one specific notion. If you spontaneously say la nieve es blanca to the relevant person at the right moment, you will teach him or her something, that is to say, reorganize a local neural network. The verb ser has a heuristic value consisting in reshaping the set of features attached to the nominal notion. In contrast, the second verb be, estar, is a hermeneutic one: la nieve está sucia, the snow is dirty. In referential semantics, it is usually said that está expresses temporary states. In cognitive terms, está conveys an indicator that the property under scrutiny is to be discontinued and will not remain permanently attached to the prototype after the utterance concerning a specific referent. Ser modifies the notion, estar only affects the referent. Besides, estar is hermeneutic in so far as it can be understood only with reference to the bundle of core properties with which the momentary one is articulated: the fact that la nieve está sucia is remarkable because the snow is supposed to be white in the first place, white meaning clean and pure. This analysis includes some notoriously tricky examples such as

(10) La fiesta es en el barracón.

(10') The party is to take place in the parish hall. 
Estar is used for locating permanent entities whose existence does not depend on spatial location, whereas in the case of fiesta we are dealing with a momentary social event which by definition takes place in a conventional place, so that if the predicate designates this location that is felt as belonging to the core properties of the subject, the verb ser has to be selected to indicate the modification of the properties of the fiesta in question, which is not the same fiesta if it occurs in the barracón or on the plaza mayor.

In very much the same way, demonstratives ese and este indicate respectively that the referent of the noun phrase is currently being defined (ese) or has already been so (este) and is merely being anaphorized:

(11) Hace unos 4.400 millones de anos, durante las últimas fases de la agregación planetaria, sus superficies fueron bombardeadas por cometas y meteoritos condríticos como revela el registro de cráteres conservados sobre algunos de ellos. Ese bombardeo masivo fue enriquecedor ya que reintrodujo los volátiles que la presión de radiación del joven Sol habia expulsado con anterioridad a regiones externas del sistema solar. (...) En esas frías zonas exteriores los volátiles se agregaron en forma de hielos formando cometas. Estos cuerpos de baja densidad al ser atraídos gravitatoriamente hacia el sistema solar interior sembrarían los cuatro mundos con los compuestos volátiles de habrían de constituir sus atmósferas.

(11') About 4,4 billion years ago, during the last stages of planet accretion, their surfaces were bombarded by comets ans chondritic meteorites as is evidenced by the record of craters that remain on some of them. This massive bombardment diversified their composition as it reintroduced the volatile chemicals which had been previously expulsed towards the outer part of the solar system. (...) In these cold exterior areas the volatiles accreted into ice, forming comets. Those low-density bodies were attracted by gravitational force towards the inner solar system, spraying the four worlds with the volatile components which were to make up their atmospheres.

The first sentence introduces the event in the form of a verb (fueron bombardeadas), the second one transforms it into a conceptual category which receives a more detailed definition (masivo). Indeed, the feature masivo had not been mentioned in the previous sentence and is introduced to modify the core properties of the bombardment so that the reader is left with the notion of a bombardment that entails the property of massiveness among its prominent characteristics (es $u n$ bombardeo masivo > ese bomabardeo masivo). The same holds true for esas frías zonas exteriores, which adds frías among the core features of zonas exteriores. Conversely, in estos cuerpos de baja densidad, the notion of baja densidad does not add any new piece of information since this property can be inferred from the previous sentence los volátiles se agregaron en forma de hielos: consciously or not, the writer of the article considered that his reader was competent enough to correctly interpret the link between the two assertions; another strategy would have been to ignore this link (esos cuerpos de baja densidad) and conceal the cause-toeffect relation. The following excerpt provides more examples of this alternation:

(12) La época de los impactos masivos. Una vez completada la acreción de los cuatro mundos interiores, parte del material restante se encontraba formando cuerpos de diferentes tamaños (algunos incluso de las dimensiones del Marte actual), cuyas órbitas cruzaban las de los planetas recién formados. Debido a esas órbitas intrusivas, las colisiones de estos 
cuerpos sobre los planetas interiores fueron habituales en esa época denominada « el gran bombardeo ».

(12') The age of the massive impacts. Once the accretion of the four inner worlds had been completed, a part of the remaining material continued forming bodies of various sizes (some of them as large as Mars as it is today) with orbits crossing those of the newly-born planets. As these orbits were intrusive, collisions between those bodies and the inner planets were frequent at this epoch known as "the big bombardment".

Ese and ser both provide heuristic definitions of the object, este and estar both presuppose that the core definition is already given and remains unaltered. This semantic common denominator is displayed in morphology by the relative morphological similarity of these operators. This strategy of transparency is motivated by an attempt at inscribing in the form of abstract grammatical operators sub-indicators which provide specific instructions to the hearer about how to reconstruct the abstract relations selected by the speaker.

\section{$\mathbf{N}$}

In initial position in grammatical morphemes, $\mathrm{N}$ habitually deals with negation: no "no", $n i$ "neither", "nor", "not (even)", nada "nothing", nadie "no one", nunca "never", ninguno "nobody". The same phenomenon is to be observed in many Indo-European languages. In previous studies I have defended the idea that $\mathrm{N}$ also serves the expression of negation when it appears in the coda of the monosyllabic grammatical morpheme as in the indefinite article an (an apple), the preposition in (the man in the street) or on (the book on the table), a few germanic past participles (driven, shaven), the nasal infinitive of German (singen), the -ing verbal flexion, and so on.

The general trend is that when $\mathrm{N}$ instanciates the onset of the syllable, it openly categorizes the operator in the field of negation. When it appears in the coda, it will apply a cognitive feature to the preceding cogneme or operator. In the case of in in English and latin, I instructs the hearer to merge the referents associated with the entities in presence (the man in the street), but $\mathrm{N}$ adds another instruction which is to reject or abort the notional merger that is made possible by the contact. If a speaker utters something like the man is the street, the notional fusion is made possible by $\mathrm{I}$ and validated by $\mathrm{S}$, so that there is a predicative relation and the whole makes a sentence, which is not ungrammatical but semantically irrelevant. A simple way to lift this ban is to regulate the notional contact by aborting the merger it is bound to entail, which is the role of $\mathrm{N}$, but then the predication is aborted too and the whole becomes a noun phrase which has to be embedded in a superordinate syntactic frame. The same analysis holds true for the indefinite article, an : if A is used as an operator of disjunction instructing the hearer to extract a sample out of a general category, negative $\mathrm{N}$ will restrict the extraction and prevent it from entailing that the sample is qualitatively different from the whole out of which it has been taken, and an apple remains perfectly representative of the general properties of the notion apple despite the singularizing effect the extraction might have. 
The same kind of description is valid for several operators in Spanish, among which the indefinite article $u n$, which I will leave aside ${ }^{4}$ as its description would require the introduction of yet another vocalic marker, $\mathrm{U}$; the preposition en, which is to be opposed to es in the same way as in contrasts with is in English; and, last but not least, the gerund, cantando "singing". The dental suffix of the past participle cantado "sung" is indicative of a process of interruption, from which the notion of perfectivation stems. If one considers the term imperfect, one will see that the notion of continuousness is obtained negatively by prefixing a negative marker which indicates that the final limit has not been reached: imperfect, imperfecto, inaccompli, infinite, this construction is very common in grammatical terminology. My contention is that in latin amans, amantis, in French chantant, in Castilian cantando, the $\mathrm{N}$ that is inserted before the dental consonant is in fact a negative infix which literally and iconically indicates that the final limit fixed by the dental has not been reached. Therefore the $\mathrm{N}$ of cantando is the marker of the same cognitive operator as the ones that are found in un, en or $n i$, no and so on; they instruct the hearer to execute the same cognemic procedure, the one that consists in aborting the procedure targeted by $\mathrm{N}$. The same construction is involved in cuando "when" (-ando applied to an unknown event, replaced by interrogative $\mathrm{cu}$ - "wh-") and probably cuanto "how much" and tanto "as much" (as opposed to todo "every", "all"), allende "beyond" (beyond displaying the same nd too). In the lexicon momento and mundo fall into the same category and tiempo "time", siempre "always", temprano "early" are potential candidates. The distinction between $\mathrm{cu}$ - and $t$ - as in cuan "how" (+ adjective) and tan "so" (+ adjective), cual "which" and tal "such" is on a par with the $w h$ - / th- distinction in English, $w$ - / $d$ - in German etc. (cataphora vs anaphora).

If the notion of interiority and inaccomplishment are both built around a negative procedure, it comes as no surprise that in many indo-european languages the corresponding operators are virtually homophonous: to be in command, to be commanding; en chantant; le danger dans la maison ("the danger in the house"), le péril en la demeure ("peril at home").

The Spanish language possesses many other operators involving the same combination of a dental preceded by a nasal and involving inaccomplishment:

-miento (derrumbamiento) « collapse » (noun)

-mienta (herramienta) « tool»

-mente (felizmente) « happily »

-ienda (una vivienda) «place where one lives»

-encia (la convivencia) « coexistence », « living together»

-ante (interesante ,interesting“, espeluznante „hair-raising“, presente „present“)

-ente (urgente ,urgent")

-ento (momento „moment“)

This model makes it possible to explain away the difference between polvoso (which is suggestive of dust), polvoriento (which emits dust) and polvoroso (which is suggestive of dust emission).

\footnotetext{
${ }^{4}$ The hypothesis of a nasal forming element common to no and un in Spanish was originally formulated by Molho 1988 in guillaumean terms: “ $(. .) *$.$n signifierait un positif entendu dans un champ$ de négativité" (p.300).
} 


\section{M}

The last cognemic morpheme to be mentioned in this study is $\mathrm{M} . \mathrm{M}$ is involved in the representation of the first person, the speaker (Bottineau 2006): $m e$ "me", $m i$ "my", mi "me" (after preposition). It regularly appears in grammatical systems in which the speaker's subjectivity is strongly involved and plays a structuring role:

Measuring quantities: muy "very", mucho "much", "a lot (of)", más "more", menos "less" / "fewer"; cf. English much, many, more, most. To those, we may add minimum and maximum and all their corresponding forms in other languages.

Drawing comparisons: como « as », « like», mismo « same», «-self», semejante "such", mientras "as", "while", "whereas", -mente "-ly" (adverbial).

In Germanic languages, the modal auxiliaries which emphasize the speaker's responsibility in the computation regularly mark this component by M: may, might and must, not to mention mood and modal, modality and other suffixes (-ism to establish a concept, -ist to refer it to a person). I have devoted one specific study to this operator and another one to $\mathrm{N}$.

\section{Conclusion}

The general theory to be drawn out of this brief overview is that there exists a universal tendency to draw units of cognitive procedures or cognemes which is manifest in languages of different types and families, among which Spanish is fairly well represented even if the system is not so systematically implemented as in English or in Basque, which is probably the most spectacular example of the phenomenon I have encountered so far, along with Japanese. Marking cognemes in morphology aims at providing the sendee of the message with a set of instructions about how to reconstruct the abstract relation induced by a grammatical operator, a problem which is not raised by lexical units, which refer to memorizable prototypes. The derivation of cognemes from sound patterns seems to be consistently available but is probably not necessary, it is one strategy which some language types favour more than others.

Moreover we have only mentioned the case in which cognemes are derived from phonemes, but in fact the same process can take its source in any systematic and stable acoustic segment of the utterance, which includes tonemes, prosodemes and syntactemes. In Spanish, for example, forefronting an adjective creates between it and its substantive the same kind of relationship as between a substantive and an article: syntatic inversion is indicative of a preexisting program that leaves no room for improvisation and leads to categorization; in English, any rising tune, no matter if it is to be found in the head or in the nucleus of the tone unit, even if it is part of complex tunes such as the fall-rise or the rise-fall, will indicate that somehow the information is incomplete, raising a question that calls for an answer, which is to come from within or outside the current utterance. Recurring syntactic and intonational patterns may also support cognemic derivation, and the way in which a given language or linguistic type focusses on cognemizing one type of acoustic pattern rather than another reveals its position and historically developed strategy in what should be known as general cognitive typology.

This model is compatible with both a mono- or polygenetic conception of the origins of language and therefore does not provide any decisive argument for or against Ruhlen's hypothesis, but it strongly militates in favour of a naturalistic approach of linguistic and cognitive phenomena. And, unexpectedly enough, it points 
towards a possible indirect biological anchoring of cognitive and linguistic functions. For more conclusive results, all this investigation is to be continued.

\section{Bibliography}

Adamczewski, H. \& Delmas, C. (1982), Grammaire Linguistique de l'Anglais, Colin, Paris.

Arapu, D. (1988), « Eléments de symbolisme dans l'expression morphologique », Bulletin de la société de linguistique de Paris, LXXXIII (compte rendu de l'exposé de la séance du 12 décembre 1987).

Austin, J.L. ( 1962), How To Do Things With Words (Oxford: Clarendon Press).

Bateson, G. (1979), Mind and Nature, a necessary unity, Bantam.

Benveniste, E. (1939), « Nature du signe linguistique », Acta Linguistica, I, Copenhagen, reprinted in (1966) Problèmes de linguistique générale, 1, Gallimard, 49-55.

Bergen, B. K. (2004), "The psychological reality of phonæsthemes", Language, $80,2,290-311$.

Bohas, G. (2006), "The organization of the lexicon in Arabic and other semitic languages", in Boudelaa, S. (ed.), Perspectives on Arabic Linguistics XVI, Papers from the sixteenth annual symposium on arabic linguistics, Cambridge, March, 2002, John Benjamins Publishing Company, Amsterdam/Philadelphia, $1-37$.

Bottineau, D. (2002), « Les cognèmes de l'anglais : principes théoriques », LOWE, R. (dir.), en collaboration avec PATTEE, J. et TREMBLAY, R., Le système des parties du discours, Sémantique et syntaxe, Actes du IXe colloque de l'Association internationale de psychomécanique du langage, Les Presses de l’Université Laval, Québec, Canada, 423-437.

Bottineau, D. (2003a), « Les cognèmes de l'anglais et autres langues », Ouattara, A. (éd.), Parcours énonciatifs et parcours interprétatifs, Théories et applications, Actes du Colloque de Tromsф organisé par le Département de Français de l'Université, 26-28 octobre 2000, Ophrys, Gap, France, 185-201.

Bottineau, D. (2003b), « Iconicité, théorie du signe et typologie des langues », MONNERET, Ph. (dir.), Cahiers de linguistique analogique, no 1 - Juin 2003, Le mot comme signe et comme image : lieux et enjeux de l'iconicité linguistique, Association Bourguignonne d'Etudes Linguistiques et Littéraires (ABELL), Dijon, 209-228.

Bottineau, D. (2003c), « De la linguistique à la traductologie : remarques sur les suffixes $-y$ et - ous et leurs traductions françaises », BALLARD, M. \& ELKALADI, A., Traductologie, linguistique et traduction, Artois Presses Université, Arras, France, 73-82.

Bottineau, D. (2004), « Le problème de la négation et sa solution dans la langue anglaise : le cognème N », DELMAS, C. \& ROUX, L., La contradiction en anglais, C.I.E.R.E.C. Travaux 116, Publications de l'Université de Saint-Etienne, 27-53.

Bottineau, D. (2005), « Prédication et interaction cognitive en basque », François, J. \& Behr, I., Les constituants prédicatifs et la diversité des langues, Mémoires de la Société de Linguistique, XIV, Peeters, Louvain, 97-132.

Bottineau, D. (2005), « Périphrases verbales et genèse de la prédication en langue anglaise », Le Querler, N. \& Bat-Zeev Shyldkrot H. (dir.), Les périphrases verbales, Lingvistica Investigationes Supplementa 25, Benjamins, 475-495. 
Bottineau, D. (2006), « Le cognème $\langle\mathrm{M}\rangle$, marque linguistique de la présence de l'auteur dans les grammèmes anglais », BANKS, D. (éd.), Les marqueurs linguistiques de la présence de l'auteur, L'Harmattan, 143-164.

Bottineau, D. (2007), «Language and enaction », Stewart, J., Gapenne, O. \& Di Paolo, E. (eds), Enaction: towards a new paradigm for cognitive science, MIT, in press.

Bourgine, P. \& Stewart, J. (2004), “Autopoiesis and Cognition”, Artificial Life 10, $327-345$.

Bybee, J. (1985), Morphology, Benjamins.

Cadiot, P. \& Visetti, Y.-M. (2001), Pour une théorie des formes en sémantiques, motifs, profils, thèmes, PUF, Paris.

Chastaing, M. (1958), «Le symbolisme des voyelles : signification des 'i' » I \& II, Journal de Psychologie, 55, 403-23 \& 461-81.

Chastaing, M. (1960), "Audition colorée : une enquête », Vie et langage, 105, 631-7.

Chastaing, M. (1961), « Des sons et des couleurs », Vie et langage, 112, 158-65.

Chastaing, M. (1962), « La brillance des voyelles », Archivum linguisticum, 14, $1-13$.

Chastaing, M. (1964), «L'opposition des consonnes sourdes aux consonnes sonores et muettes : a-t-elle une valeur symbolique? », Vie et langage, 147, 367-70.

Chastaing, M. (1965a), « Dernières recherches sur le symbolisme vocalique de la petitesse », Revue philosophique, 155, 141-56.

Chevalier, J.-C. (1980), « Mot et sens du mot», Joly, A. \& Hirtle, W. (eds), Langage et psychomécanique du langage, Etudes dédiées à Roch Valin, Presses de L'Université de Lille, Presses de L'Université Laval - Québec, 75-86.

Chevalier, J.-C., Launay, M. et Molho, M. (1984), « La raison du signifiant », Modèles Linguistiques, 6/2, 12, 27-41.

Chevalier, J.-C., Launay, M. et Molho, M. (1986), « Pour une linguistique du signifiant », Actes des Colloques de Linguistique Hispanique 1, 95-99.

Cotte, P. et al., Les théories de la grammaire anglaise en France, Hachette, 1993.

Coursil, J. (2000), La fonction muette du langage, Ibis Rouge Éditions, presses Universitaires Créoles, Guadeloupe.

Culioli, A. ([1981] 1990), « Sur le concept de notion », BULAG no8, repris dans Pour une linguistique de l'énonciation, $t .1$ : Opérations et représentations, Ophrys.

Curat, H. (1991), Morphologie verbale et référence temporelle en français moderne, Droz, Genève.

Danon-Boileau, L. (1983), «This, that, which, what et la construction de la référence », Travaux du CIEREC XXXIX, Méthodes en linguistique anglaise, Université de Saint-Etienne.

Danon-Boileau, L. (1991), « De quelques préjugés relatifs à l'usage des notions de motivation et d'iconicité », Faits de langues, 1, Motivation et iconicité, PUF, 79-87.

Darbord, B. (1994), « Sur le contenu de la forme en ra en espagnol et en portugais », Actes des Colloques de Linguistique Hispanique 5, 313-323.

Davis, J., Gorup, R. J. \& Stern, N. (Eds) (2006), Advances in Functional Linguistics, Columbia School beyond its origins, Studies in Functional and Structural Linguistics 48, John Benjamins. 
Delmas, C. (1987), Structuration abstraite et chaîne linéaire en anglais contemporain, Klincksieck.

Dennett, D.C. (1991), Consciousness Explained. Boston: Little, Brown and Co.

Dessalles, J-L. (2000), Aux origines du langage - Une histoire naturelle de la parole, Hermès, Paris.

Diver, W. (1979), "Phonology as human behavior," in D. Aaronson and R. Rieber (eds.), Psycholinguistic research: implications and applications. Hillsdale, N.Y., Lawrence Erlbaum Assoc., 161-182.

Douay, C. (2000), Eléments pour une théorie de l'interlocution, Un autre regard sur la grammaire anglaise, Presses Universitaires de Rennes.

Duchet, J.-L. (1990), « Arbitraire et motivation dans le lexique et la morphologie de l'anglais », ROUX, L. (ed), L'organisation du sens, domaine anglais, Recueil en l'honneur de Jean Lavédrine, Travaux du CIEREC, LXVIII, 57-66.

Edelman G. (1989), The remembered present: a biological theory of consciousness, Basic Books, New York.

Engler, R. (1962), « Théorie et critique d'un principe saussurien. L'arbitraire du signe », Cahiers Ferdinand de Saussure, 19, 5-66.

Engler, R. (1964), «Compléments à l'arbitraire », Cahiers Ferdinand de Saussure, 21, 25-32.

Erard, Y., « De l'énonciation à l'enaction. L'inscription corporelle de la langue », Cahiers de l'Institut de Linguistique et des Sciences du Langage, $n^{\circ} 11$, Mélanges offerts en hommage à Mortéza Mahmoudian, tome I et II.

Feldman, J., \& Narayanan, S. (2004). "Embodied meaning in a neural theory of language". Brain and Language, 89, 385-392.

Firth, J.-R. (1930) Speech, London, Ernest Benn.

Fischer, O., \& Nänny, M. (eds.) (2001), The Motivated Sign : Iconicity in Language and Literature 2, Benjamins, 249-276.

Fischer Jorgensen, E. (1978), « On the universal character of phonetic symbolism with special reference to vowels », Studia linguistica, 32, 80-90.

Fónagy, I. (1983), La vive voix, essai de psycho-phonétique, Payot.

Gallese, V., \& Lakoff, G. (2005), The brain's concepts: the role of the sensory-motor system in conceptual knowledge. Cognitive Neuropsychology, 22 (3/4), 455-479.

Gardiner, A. H. ([1932] 1951), The Theory of Speech and Language, Oxford, Clarendon Press.

Gardner, H. (1985), The mind's new science: a history of the cognitive revolution. Basic Books, New York.

Genette, G. (1976), Mimologiques, Seuil.

Givon, T. (1994), "On the Co-evolution of Language, Cognition and Neurology". Paper for 10th meeting of Language Origins Society, Berkeley.

Grammont, M. (1933), Traité de phonétique, Delagrave, 377-424.

Gregory, R.L. (1976), Concepts and mechanisms of perception. London: Duckworth.

Guillaume, G. (1964), Langage et science du langage, Paris, Québec, Nizet/P. U. Laval.

Guiraud, P. (1986), Structures étymologiques du lexique français, Payot.

Heine, B. (1997). Cognitive foundations of grammar. New York: Oxford University Press. 
Householder, F. W. (1946), « On the Problem of Sound and Meaning, an English Phonestheme », World 2, 83 sq.

Jacob F. (1970), La logique du vivant, Gallimard, Paris.

Jakobson, R. (1963), Essais de linguistique générale. Tome I : les fondations du langage. Paris : Editions de Minuit, 1963.

Jakobson, R. \& Waugh, L. ([1979] 1980), La charpente phonique du langage, Minuit.

Jespersen, O. ([1922] 1933), « Symbolic value of the vowel i », Linguistica, College Park, Maryland, 283-303.

Keller, P.-H. (2006), Le dialogue du corps et de l'esprit, Odile Jacob, Paris.

Kemp, J. A. (1972), John Wallis's Grammar of the English Language, Longman.

Kravchenko, A. V. (2004), "Essential properties of language from the point of view of autopoiesis", http://cogprints.org/4008/01/PropertiesOfLanguage.pdf

Lakoff, G. \& Johnson, M. (1999), Philosophy In The Flesh: the Embodied Mind and its Challenge to Western Thought, Basic Books.

Langacker R.W. (1987), Foundations of cognitive grammar. Stanford University Press, Stanford.

Lapaire, J.R. \& Rotgé, W. (1993), Linguistique et Grammaire de l'Anglais, Presses universitaire du Mirail, Toulouse.

Larthomas, P. (1988), « Notes sur ça, ci et l'alternance i/a en français », Grammaire et histoire de la grammaire, Hommage à la mémoire de Jean Stéfanini, recueil d'études rassemblées par Blanche-Benveniste, C., Chervel, A. \& Gross, M., Publications de l'Université de Provence, 271-9.

Launay, M. (1987), «Signe, signifiant, signifié : leçons de Saussure et de Guillaume » in Chevalier, J.-C., Delport, M.-F. et Vich-Campos, M. (éds.) (1987), Mélanges offerts à M. Molho. III : Linguistique - Fontenay-aux-Roses, ENS, $\mathrm{N}^{\circ}$ spécial de Les Cahiers de Fontenay (vol. 46-48),139-159.

Leroi-Gourhan A. (1964), Le geste et la parole. I. Technique et langage. II. La mémoire et les rythmes, Albin Michel, Paris.

Lieberman, P. (1991), Uniquely Human: The Evolution of Speech, Thought, and Selfless Behavior. Cambridge, MA: Harvard University Press.

Luquet, G. (1996a), "Un caso de motivación del signo lingüístico : oposición regular / irregular en la historia de los pretéritos indefinidos", in Alonso González, A. et alii (éds.) - Actas del III Congreso Internacional de Historia de la Lengua Española (Salamanca, 22-27 November 1993), Arco Libros, Madrid, 403410.

Luquet, G. (1996b) - "Arbitrariness and Non-Arbitrariness in the Historical Evolution of Language" in Tollis, F. (ed.), The Psychomechanics of language and guillaumism $=$ LynX $($ Valence et Philadelphie), 5, 154-157.

Luquet, G. (2004), La teoría de los modos en la descripción del verbo español. Un nuevo planteamiento, Madrid, Arco / Libros.

Macchi, Y. (1986), « Du rôle du signifiant dans la genèse du sens énonciatif », Langages, 82, 67-82.

Macchi, Y. (1991) «Halte aux manipulations sémiques : de la métaphore chimique en sémantique », Modèles Linguistiques, 13/1, 25 101-116.

Marchand, H. (1959), «Phonetic Symbolism in English Word-Formation », Indogermanische Forschungen, 64, 146-68, 256-77.

Markel, N. N. \& Hamp, E. P. (1960-1), « Connotative Meanings of Certain Phoneme Sequences », Studies in Linguistics, 15, 47-61. 
Maturana, H. (1978), "Biology of language: The epistemology of reality", in Miller, G., and E. Lenneberg (eds.), Psychology and Biology of Language and Thought: Essays in Honor of Eric Lenneberg, New York: Academic Press, 1978, 27-64.

Maturana H.R. \& Varela F.J. (1980). Autopoiesis and cognition: the realization of the living. Reidel, Dordrecht.

Maturana H. \& Varela F.J. (1987), The Tree of Knowledge: the biological roots of human understanding, Shambhala, Boston, London.

McNeill, D. (2005), Gesture and thought, Chicago \& London: University of Chicago Press.

Molho, M. (1958), “Acerca de la evolución del grupo -skl- -sl-en romance”, Archivo de filología aragonesa, 8-9, p. 63-71.

Molho, M. (1980), «Verbe et personne. De l'arbitraire du signe », Cahiers de linguistique hispanique médiévale, 5, 5-23.

Molho, M. (1986), « Grammaire analogique, grammaire du signifiant », Langages, 82, Le signifiant, 41-51.

Molho, M. (1988), «L'hypothèse du «formant » : sur la constitution du signifiant : esp. un/no », Grammaire et histoire de la grammaire, Hommage à la mémoire de Jean Stéfanini, recueil d'études rassemblées par Blanche-Benveniste, C., Chervel, A. \& Gross, M., Publications de l'Université de Provence, 291-303.

Newman, S. S. (1933), « Further Experiments in Phonetic Symbolism », American Journal of Psychology, 45, 53-75.

Oudeyer, P.-Y. (2006), Self-organization in the evolution of speech, Oxford.

Peirce, C. S. [1894] "What is a Sign", In: Houser; Kloesel (eds). The Essential Peirce. Selected Philosophical Writings. Vol 2. (1893-1913), Indiana University Press.

Philps, D. (1997), «A la recherche du sens perdu : 〈sn->, du marqueur au mythe », Anglophonia, 2, English Linguistics, 209-38, Presses Universitaires du Mirail, Toulouse.

Philps, D. (2003), «L'invariance sub-lexicale et le marqueur», Anglophonia / Sigma 14, Toulouse : Presses Universitaires du Mirail : 177-193.

Reid, W., Otheguy, R. \& Stern, N. (eds) (2002), Signal, Meaning, and Message, Perspectives on sign-based linguistics, John Benjamins.

Robert, S. (éd.). (2003), Perspectives synchroniques sur la grammaticalisation, Peeters, Louvain-Paris.

Robert, S. \& Chapouthier, G. (2006), "The Mosaic of Language”, Marges linguistiques - Issue $\mathrm{N}^{\circ} 11$, May 2006 - M.L.M.S. Publisher, 160-166. http:// www.marges-linguistiques.com - 13250 Saint-Chamas (France)

Rousseau, A. (2005), «La notion de « schème cognitif » en typologie des langues », in Lazard, G. \& Moyse-Faurie, C. (eds), Linguistique typologique, Presses Universitaires du Septentrion, Villeneuve d'Ascq, France.

Salzen, E. A. (2006), "From Calls to Words : How ethology can bridge the divide", Marges linguistiques - Numéro 11, Mai 2006 - M.L.M.S. éditeur, 200-217, http://www.marges-linguistiques.com - 13250 Saint-Chamas (France)

Schmidely, J. (1988), "La -y de doy, estoy, soy, voy" in Ariza M., Salvador, A. et Viudas, A. (éds.), Actas del I Congreso Internacional de Historia de la Lengua Española (Cáceres, 30 marzo-4 abril 1987) Arco Libros, Madrid, I, 611-619. 
Schogt, H. (1992), " Onomatopées, mots expressifs et la métaphore en phonétique », Mélanges Pierre Léon, Martin, P. (dir), Toronto, Mélodie, Canadian Scholars' Press et Didier Erudition, Paris, 463-71.

Shanon, B. (1993), The Representational and The Presentational: An essay on cognition and the study of mind. London: Harvester-Wheatsheaf.

Stewart, J. (1996). Cognition = Life : Implications for higher-level cognition. Behavioural Processes 35: 311-326.

Studdert-Kennedy, M., \& Goldstein L. (2003). Launching language: the gestural origin of discrete infinity. In M. H. Christiansen \& S. Kirby (Eds.), Language evolution (pp. 235-254). Oxford: Oxford University Press.

Talmy, L. (2000), Toward a Cognitive Semantics, volumes I and II, MIT Press.

Tobin, Y. (1993), Aspect in the English Verb, Longman.

Tobin, Y. (1997), Phonology as human behavior: Theoretical implications and clinical applications. Durham \& London: Duke University Press.

Tollis, F. (1998a), « À propos de la prétendue "négativité" de algún in Estudios en honor del Profesor Josse de Kock, Leuven University Press, 519-528.

Tollis, F. (1998b), « Le couplage analytique des morphèmes en /un/- et en -/l/-, vu de l'espagnol » in Leeman, Danielle, Boone, Annie et alii, Du percevoir au dire. Hommage à André Joly, L'Harmattan, Paris :, 132-145.

Toussaint, M., (1983), Contre l'arbitraire du signe, Paris, Didier.

Varela F., Thompson E. \& Rosch E. (1993). The Embodied Mind: Cognitive Science and Human Experience. MIT Press, Cambridge.

Viel, M. (1993), «L'opposition i-æ en anglais : ordre des voyelles, ordre des mots, iconicité », L'ordre des mots II - Domaine anglais, CIEREC, Travaux LXXXI, 181-193, Saint-Etienne.

Vygotsky L.S. (1962), Thought and Language. E.Kaufamnn \& G.Vakar, eds \& trans., MIT Press, Cambridge.

Wallis, J. (1653). Grammatica linguce anglicance. R.C. Alston (Ed.), Reprint 142 (1969). Menston: The Scolar Press.

Waugh, L. (1993), «Lexique : iconicité diagrammatique », Faits de langues, 1, Motivation et iconicité, PUF, 227-34.

Whorf, B. Lee. (1956), Language, thought, and reality: selected writings of Benjamin Lee Whorf., Ed. J.B. Carroll, MIT Press, Cambridge.

Wilson, M. (2002), "Six views of embodied cognition". Psychological Bulletin and Review, 9(4), 625-636.

Ziemke, T. (2002), "What's that thing called embodiment?" in Proceedings of the 25th Annual Meeting of the Cognitive Science Society, Lawrence Erlbaum, 1305-1310. 